\title{
Claiming the sea area belonging to Sri Lanka according to the United Nations Convention on the Law of the Sea (UNCLOS)
}

The United Nations Convention on the Law of the Sea (UNCLOS) provides a comprehensive legal and scientific framework for addressing various issues related to oceanic areas. One of the most important achievements of UNCLOS is the successful formulation of a set of criteria that determines the extent of sea area that a maritime country can claim under its jurisdiction. These criteria have been incorporated in the Article 76 of the convention and in the Annex II of the final Act.

Article 76 of the convention provides the basis for a maritime country to demarcate its maritime boundaries. Paragraph 1 of the article 76 of UNCLOS states that the "continental shelf" of a maritime state comprises the seabed and sub-soil of the submarine areas that extend beyond its territorial sea throughout the natural prolongation of its land territory to the outer edge of the continental margin. The continental margin of a maritime state consists of the submerged prolongation of the seabed / sub-soil of the continental shelf, slope and rise.

All the measurements related to demarcation of maritime boundaries have to be made from a baseline which is defined as the low water line of the maritime country that is normally used for surveying purposes. A maritime state can demarcate its outer edge of the continental margin using one of the formulae provided in paragraph 4(a) of the Article 76. The first formula is known as the sediment formula or Irish formula and it allows a maritime state to claim the adjacent sea area up to a boundary where the thickness of oceanic sediments is $1 \%$ of the distance measured from the foot of the slope. This boundary should not exceed 350 nautical miles from the baseline mentioned above. The second formula which is known as the Hedberg formula, named after a renowned American geologist Hollis Hedberg, states that a maritime country can claim the adjacent sea area up to a distance not more than 60 nautical miles from the foot of the continental slope. This boundary should not exceed 100 nautical miles from the $2500 \mathrm{~m}$ isobath. In both these formulae, the foot of the continental slope means the point at which the bathymetry shows the maximum change in slope.

In response to submissions made by the Government of Sri Lanka with regard to inequity that would arise to Sri Lanka as a result of application of Article 76, a special method of establishing maritime boundaries for countries south of the Bay of Bengal has been formulated during the Third United Nations Conference of the Law of the Sea held in 1982. This special method has been incorporated in the Annex II of the final Act as a statement of understanding and is applicable for maritime states, which satisfy the following criteria;

1. Average distance at which the $200 \mathrm{~m}$ isobath occurs is not more than 20 nautical miles from the baseline.

2. Mathematical average of thickness of sedimentary rocks lying along the boundary established at the maximum permissible distance according to Article 76 would not be less than $3.5 \mathrm{~km}$.

It is generally understood that Sri Lanka can satisfy the above criteria and use Annex-II to delimit its outer edge of continental margin. In claiming the outer edge of the continental margin of Sri Lanka beyond the exclusive economic zone using Annex II, it is necessary to determine the boundary at which thickness of sediments lying in the Indian Ocean region around Sri Lanka is one kilometer. Technical guidelines issued by the convention for this purpose recommend that multi-channel seismology is the most suitable method for this purpose. The government of Sri Lanka set up a special project under the purview of the Ministry of Foreign Affairs and the Ministry of Fisheries and Aquatic Resources to carry out scientific surveys related to the demarcation of maritime boundaries of Sri Lanka. With the help of a group of dedicated geologists, geophysicists and hydrographers, some of whom were working on a voluntary basis; initial planning of the seismic survey was carried out. This involved determining the approximate boundary of the outer edge of the continental margins using results of 
single channel seismic work carried out over the region by some geophysical institutes in the USA, Germany and Russia, the Deep Sea Drilling Project (DSDP) and results of interpretation of satellite gravity anomalies carried out by local geophysicists. According to the results of these studies Sri Lanka can claim an oceanic area almost equal to twenty-five times of its land area. This area covers a large extent of the southern part of the Bay of Bengal with a thick sediment cover having a high potential of hydrocarbon accumulation.

In the early part of 2007, the DEOCOM project (Delimitation of the Outer Edge of the Continental Margin of Sri lanka) commissioned a UK based geophysical company, Gems Geophysical Ltd. to conduct a geophysical survey following the cruise tracks based on the results of the above mentioned studies. In this survey, reflection seismic and gravity data were acquired over a distance of approximately $7000 \mathrm{~km}$ using the research vessel MV Geo Searcher over a period of about seventy days. Using the results of this survey, Sri Lanka's claim was prepared by a group of local scientists and legal experts with the assistance of several foreign experts who have been involved in the preparation of similar claims for their own countries. The deadline imposed by the UN Commission for maritime countries to make their submissions was $13^{\text {th }}$ May 2009. Sri Lanka was successful in making its submission on $8^{\text {th }}$ May 2009. However, over forty two maritime countries had submitted their claims before us and the date on which our claim will be considered by the UN Commission on the Limits of the Continental Shelf (CLCS) will be delayed as a result of this.
Considering the number of countries making their submissions prior to us, it is unlikely that our claim will be taken up for hearing before 2025 and therefore we should have a group of competent Sri Lankan scientists and legal experts ready by that time to defend our claim. Undoubtedly, the most competent people to defend Sri Lanka's claim at the CLCS are those who were involved in the preparation of the claim. Most of the scientists and legal experts who took part in the preparation of the claim are very senior people and it is unlikely that they will be in active service in another 15 years time. Therefore, there should be a comprehensive programme to transfer this knowledge to a younger generation who can successfully defend the claim in 2025 . One way of achieving this is by making funding available for studies related to the geology and geophysics of the Indian Ocean around Sri Lanka and also focussing on the legal issues related to delimitation of continental margins. These studies can be carried out at postgraduate level at Sri Lankan Universities with those who were involved in preparation of the original claim as their research supervisors.

Vast amounts of gravity and seismic data collected around Sri Lanka during the survey carried out by the DEOCOM can be gainfully utilized for this purpose. Academic studies at postgraduate level using this data will certainly ensure smooth transfer of knowledge to the younger generation, thus establishing a vital link between the experts of today and those of tomorrow, paving the way for the successful defense of our claim for the outer edge of the continental margins of Sri Lanka in 2025.

D.A. Tantrigoda 